\title{
THE USE OF PUPPET: SHIFTING SPEAKING SKILL FROM THE PERSPECTIVE OF STUDENTS' SELF-ESTEEM
}

\author{
Suesthi Maharani \\ English Education Department of Graduate Program of Teacher Training and \\ Education Faculty of Sebelas Maret University \\ Email: swez.maharanny@yahoo.com
}

\begin{abstract}
This article reports the result of a research dealing with, 1) the difference between Puppet and Picture in teaching speaking, 2) the difference between students having high self-esteem and students having low self-esteem, and 3) the interaction between teaching media and self-esteem. The samples were two classes namely experimental class taught by using Puppet and control class taught by using Picture. Each class was divided into two groups in which each consisted of students having high self-esteem and those having low self-esteem. To collect the data, two instruments were used namely speaking test and self-esteem questionnaire. The data were, then, analysed by using descriptive statistics to describe the research data and inferential statistics namely multifactor Analysis of Variance ANOVA $2 x 2$ and Tukey test to test the hypotheses. The findings of this research are: (1) Puppet is more effective than Picture to teach speaking; (2) The students having high self-esteem have better speaking skill than those having low self-esteem; and (3) There is an interaction between teaching media and students' self-esteem in teaching speaking. Based on the research findings, it could be summarized that Puppet is an effective media in teaching speaking to the eighth grade students of one of junior high schools in Semarang Regency in the academic year of 2014/2015. The effectiveness of the media is affected by self-esteem.
\end{abstract}

Keywords: Puppet media, picture media, speaking skill, self-esteem, experimental research.

\section{INTRODUCTION}

Students often value speaking more than the other skills of reading, writing and listening. They often feel a great deal of anxiety related to their oral production. Meanwhile, the goal of language is communication and the aim of speaking in a language context is to promote communicative efficiency. That is why students have to be able to use the language as correctly as possible and with a purpose to deliver message or information orally. They should try to overcome the anxiety to speak in English and to avoid confusion in the message due to faulty of pronunciation, grammar, vocabulary, and fluency. Because learning speaking is a habit formation, it needs practicing as often as possible. 
Media is one of the important things to support teaching speaking and very determinative in the learning achievement. There are many kinds of media: visual, audio, and audio visual. According to Levie, visual media is interesting to students, increasing of students' understanding, giving the material accurately and accountable, giving information accurately; and easily to be understandable and easily to be interpreted. Additionally, visual media is more simple and easy to bring any where (Agil, 2012). One of visual media to support teaching and learning speaking is puppet. As stated in Reidmiller (2008), the use of a puppet can provide help with public speaking, especially for the shy or apprehensive student. Puppet activities keep students actively engaged with hands-on activities. It can increase the students' involvement, motivation, and the development of student's reading, oral language, and communication skills. The other example of attractive visual media is picture. Generally, this media is used because it is concrete. It means that the students can identify or imagine the real object drawn in the picture in giving statement of it. The primary purpose of this media is to make students easy to understand in giving opinion or probably perception of the picture.

In learning speaking, the factors influencing is not only the media used by the teacher, but also the psychological aspects such as self-esteem. Brown in Kalanzadeh (2013) proposes that no successful cognitive or affective activity can be carried out without some degree of self-esteem, self-confidence and self-efficacy in your own capabilities to successfully perform that activity. Related to students' self-esteem in learning, the students are supposed to have appreciation and trust themselves to involve or participate in teaching learning process to gain knowledge.

According to the observation, it was found that the students got some problems in speaking skill. Therefore, it was necessary for the writer to conduct a research on students' speaking to find what media that was effective to solve the students' problems.

This research is aimed at identifying the effect of the teaching media and self-esteem on students' speaking skill. Particularly this research is proposed: (1) Whether the Puppet media is more effective than the Picture media to teach speaking for the eighth grade students of one of junior high schools in Semarang Regency; (2) Whether the students of 
the eighth grade of one of junior high schools in Semarang Regency whose self-esteem is high have better speaking skill than those whose self-esteem is low; (3) Whether there is any interaction between the teaching media and students' self-esteem to teach speaking.

Speaking is important way in communication in order to build a good relationship with others. For building a good communication, people must have a good speaking skill. Thornbury (2005: 2-14) states that the word "speaking" has close relation to the language skill in the oral mode or speech production. It is one's ability to produce speech or oral language due to the complete knowledge of the language which has various areas of speaking; transactional function refers to purpose of conveying information and facilitating the exchange of goods and services, whereas interpersonal function refers to all about maintaining and keeping good relations between people. Fulcer (2003: 23-29) states that speaking is the verbal use of language to express ideas, opinion, and feelings. According to Hymes (1972: 269), speaking is the ability of being able to produce and comprehend utterances which are appropriate to the context in which they are made. Florez (1999: 1) says that speaking is an interactive process of constructing meaning both its form and meaning depend on the context, the participants, their experiences, the environment and the purpose for speaking. Considering some definitions, it could be inferred that speaking skill is an ability to produce speech or oral language by comprehending, expressing, and sharing ideas, opinions or feelings depending on the context, participant, experience, environtment, and purpose.

Belfiore (2013) states that puppet is defined as a movable inanimate object or figure that is controlled by strings, rods, or by placing one's hand inside its body. Puppet refers to material images of humans, animals, or spirits that are created, dis-played, or manipulated in narrative or dramatic performance (Bell, 2001). It could be concluded that puppet is a movable inanimate object representing an image of humans, animals, or spirit which is created, displayed and controlled by strings, rods, or by placing one's hand inside its body.

Hornby (1995: 871) defines picture as a painting, drawing, sketch, etc especially as a work of art. While Mckenchnie (1980: 1357) defines picture in Webster dictionary that picture is an image, or likeness of an object, person, or scene produce on a flat surface, 
especially by painting, drawing or photography. Gerlach (1980: 273) states that pictures are a two dimension visual representation of person, places, or things. Meanwhile, according to Wright (1989: 29), picture is not just an aspect of method but through its representation of place, object, and people, it is essential part of the overall experiences. It could be concluded that picture is a painting, drawing, sketch or photograph on a flat surface which is defined as a likeness of person, place, thing or idea, which is clearly visible, striking, and colorful to visual material.

Self-esteem is defined as the perception of self-worth, or the extent to which a person values. Charles (2007) states that self-esteem is how much someone values himself and how important he thinks he is. It's knowing he is worthy of love and respect and accepting his limitations and boundaries. It's how he sees himself and how he feels about his achievements. In Rubio (2007), Branden (1994) said that self-esteem is the disposition to experience oneself as being competent to cope with the basic challenges of life and of being worthy of happiness. Rubio (2007) himself defines self-esteem as a psychological and social phenomenon in which an individual evaluates his/her competence and own self according to some values. According to some theories which had been stated, it could be simplified that self-esteem is a psychological aspect related to a sense of self-worth or personal value about feeling, assumption and belief toward one's own appearance and competence.

\section{RESEARCH METHODOLOGY}

The research was conducted in one of junior high schools in Semarang Regency from January 2015 to March 2015. This research was carried out at the second grade students in the academic year of 2014-2015.

There is a dependent variable and two independent variables in this research. The dependent variable is speaking skill and the independent variables are teaching media and self-esteem. The teaching media used in the class in order to achieve the objectives were puppet media and picture media. Puppet media was used to teach speaking in experimental class. And then, picture media was used to teach speaking in control class. The last variable was self-esteem as attributive variable provided as psychological aspect. The design of this research was a factorial design $2 \times 2$ with post- test only design to assess the effect of two or more independent variables on the dependent variable. The population of this research is the eighth grade students of one of junior high schools in Semarang Regency in the academic year of 2014/2015. This research was conducted in two classes, one class as the 
experimental group and one as the control group. The number of the students in each class is 30 students, so there were 60 students as sample. And the writer used cluster random sampling.

The writer used two instruments of collecting data in this study. There were speaking test and self-esteem questionnaire. Speaking test was used to measure the students' speaking skill by using scoring rubrics of speaking. Speaking test was assessed by using readability of the test instruction which informs whether the test instructions are appropriately readable for students and whether the instruction of speaking test can be understood by the students. And the result of the questionnaire showed that more than $75 \%$ of students answered "Yes" for each item in the instruction. It could be concluded that speaking test in this research is readable. And then, self-esteem questionnaire was used to measure the level of students' self-esteem and it was assessed by using validity and reliability test. Validity test is used to identify whether each item is valid or not, while reliability test is used to identify whether the instrument is reliable or not.

The techniques used in analyzing the data were descriptive analysis and inferential analysis. Descriptive analysis was used to know the mean, median, mode and standard deviation of the scores of the speaking test. To identify the normality and the homogeneity of the data, the reseacher used normality and homogeneity test which were done before testing the hypothesis. Inferential analysis used was multifactor analysis of variance $2 \times 2$ to test the hypotheses. $\mathrm{H}_{\mathrm{o}}$ is rejected if $\mathrm{F}_{\mathrm{o}}$ is higher than $\mathrm{F}_{\mathrm{t}}$. If $\mathrm{H}_{\mathrm{o}}$ is rejected, the analysis was continued to identify which group is better by using Tukey test.

\section{DISCUSSION}

The data in this research are classified into eight groups: (1) The data of students' speaking score taught by using Puppet media $\left(\mathrm{A}_{1}\right)$; (2) The data of students' speaking score taught by using Picture media $\left(\mathrm{A}_{2}\right)$; (3)The data of speaking score of the students having high self-esteem $\left(\mathrm{B}_{1}\right)$; (4) The data of speaking score of the students having low self-esteem $\left(\mathrm{B}_{2}\right)$; (5) The data of speaking score of the students having high self-esteem taught by using Puppet media $\left(\mathrm{A}_{1} \mathrm{~B}_{1}\right)$; (6) The data of speaking score of the students having low self-esteem taught by using Puppet media $\left(\mathrm{A}_{1} \mathrm{~B}_{2}\right)$; (7) The data of speaking score of the students having high self-esteem taught by Picture media $\left(\mathrm{A}_{2} \mathrm{~B}_{1}\right)$ and $(8)$ The data of speaking score of the students having low self-esteem taught by Pictur media $\left(\mathrm{A}_{2} \mathrm{~B}_{2}\right)$.

The result of normality test for the eight groups shows that all the data of speaking scores for the eight groups are in normal distribution because $\mathrm{L}_{\mathrm{o}}$ of the entire data are lower than $\mathrm{L}_{\mathrm{t}}\left(\mathrm{L}_{\mathrm{o}}<\mathrm{L}_{\mathrm{t}}\right)$ at the level of significance $\alpha=0.05$. The summary of normality test could be seen in the Table 1 .

Table 1. The Summary of Normality Test

\begin{tabular}{cccccc}
\hline Data & $\begin{array}{c}\text { Number of } \\
\text { Sample }\end{array}$ & Lo & Lt & $\boldsymbol{\alpha}$ & $\begin{array}{c}\text { Distribution } \\
\text { of Sample }\end{array}$ \\
\hline $\mathrm{A}_{1}$ & 30 & 0.088 & 0.161 & 0.05 & Normal \\
\hline $\mathrm{A}_{2}$ & 30 & 0.085 & 0.161 & 0.05 & Normal \\
\hline $\mathrm{B}_{1}$ & 30 & 0.083 & 0.161 & 0.05 & Normal \\
\hline
\end{tabular}




\begin{tabular}{cccccc}
\hline $\mathrm{B}_{2}$ & 30 & 0.060 & 0.161 & 0.05 & Normal \\
\hline $\mathrm{A}_{1} \mathrm{~B}_{1}$ & 15 & 0.081 & 0.220 & 0.05 & Normal \\
\hline $\mathrm{A}_{1} \mathrm{~B}_{2}$ & 15 & 0.111 & 0.220 & 0.05 & Normal \\
\hline $\mathrm{A}_{2} \mathrm{~B}_{1}$ & 15 & 0.129 & 0.220 & 0.05 & Normal \\
\hline $\mathrm{A}_{2} \mathrm{~B}_{2}$ & 15 & 0.127 & 0.220 & 0.05 & Normal \\
\hline
\end{tabular}

The result of homogeneity test is 3.42 . The data are homogeneous if $\chi_{\mathrm{o}}{ }^{2}\left(\chi_{\text {obtained }}\right)$ is lower than $\chi_{t}^{2}\left(\chi_{\text {table }}\right)$ at the level of significance $\alpha=0.05$. Because $\chi_{o}^{2}(3.42)$ is lower than $\chi_{t}^{2}$ (7.81), it could be said that the data are homogeneous. It means that the data of this research are obtained from homogeneous sample. The details could be seen in the Table 2.

Table 2. Summary of Homogeneity Test

\begin{tabular}{ll}
\hline$s^{2}$ & $\mathbf{2 2 . 8 2}$ \\
\hline $\log \mathrm{s} 2$ & $\mathbf{1 . 3 6}$ \\
\hline $\mathrm{B}=\left(\log \mathrm{s}^{2}\right) \Sigma\left(\mathrm{n}_{\mathrm{i}}-1\right)$ & $\mathbf{7 6 . 0 6}$ \\
\hline $\ln 10$ & $\mathbf{2 . 3 0 2 6}$ \\
\hline$\chi^{2}=(\ln 10)\{B-$ & $\mathbf{3 . 4 2}$ \\
$\left.\sum\left(n_{i}-1\right) \log S_{i}^{2}\right\}$ & \\
\hline
\end{tabular}

\begin{tabular}{llllll}
\hline Sample & $\mathbf{d f}$ & $\mathbf{1 / ( d f )}$ & $\mathbf{s}_{\mathbf{i}}{ }^{2}$ & $\log \mathbf{s}_{\mathbf{i}}{ }^{2}$ & $(\mathbf{d f}) \log \mathbf{s}_{\mathbf{i}}{ }^{2}$ \\
\hline 1 & 14 & 0.0714286 & 13.56 & 1.1322 & 15.8514 \\
\hline 2 & 14 & 0.0714286 & 21.20 & 1.3262 & 18.5673 \\
\hline 3 & 14 & 0.0714286 & 35.98 & 1.5561 & 21.7850 \\
\hline 4 & 14 & 0.0714286 & 20.53 & 1.3124 & 18.3730 \\
\hline & $\mathbf{5 6}$ & & & & $\mathbf{7 4 . 5 7 6 8}$
\end{tabular}

After the data are normal and homogeneous, then the data are analysed by using Multifactor Analysis of Variance (ANOVA) 2x2 which could be seen in the table 1. This test is used to identify the effects of the independent variables and attributive variable toward the dependent variable. In addition, it functions to check if there is an interaction among those variables. The hypothesis is rejected if $F_{o}$ is higher than $F_{t}\left(F_{o}>F_{t}\right)$.

The computation of hypotheses test by using ANOVA Test could be seen in the Table 3 and the result of mean score could be seen in the Table 4.

Table 3. Multifactors Analysis of Variance (ANOVA) 2x2 


\begin{tabular}{lccccc}
\hline Source variance & $\mathrm{SS}$ & $\mathrm{df}$ & $\mathrm{MS}$ & $\mathrm{F}_{\mathrm{o}}$ & $\mathrm{F}_{\mathrm{t}(0.05)}$ \\
\hline Between columns $\left(\sum \mathrm{x}_{\mathrm{bc}}{ }^{2}\right)$ & 92.50 & 1 & 92.50 & 4.05 & 4.00 \\
\hline Between rows $\left(\sum \mathrm{x}_{\mathrm{br}}{ }^{2}\right)$ & 199.00 & 1 & 199.00 & 8.76 & \\
\hline Columns by rows $\left(\sum \mathrm{x}_{\mathrm{int}}{ }^{2}\right)$ & 119 & 1 & 119 & 5.22 & \\
\hline Between groups $\left(\sum \mathrm{x}_{\mathrm{b}}{ }^{2}\right)$ & 411.35 & 3 & 137.12 & & \\
\hline Within groups $\left(\sum \mathrm{x}_{\mathrm{w}}{ }^{2}\right)$ & 1277.70 & 56 & 22.82 & & \\
\hline Total $\left(\sum \mathrm{x}_{\mathrm{t}}{ }^{2}\right)$ & 1689 & 59 & & & \\
\hline
\end{tabular}

Table 4. The Result of Mean Score

\begin{tabular}{cccc}
\hline \multirow{2}{*}{ Self-esteem (B) } & \multicolumn{2}{c}{ Teaching Media (A) } & \\
\cline { 2 - 3 } & $\begin{array}{c}\text { Puppet Media } \\
\text { (A1) }\end{array}$ & $\begin{array}{c}\text { Picture Media } \\
\text { (A2) }\end{array}$ & \\
\hline High Self-esteem (B1) & 84.83 & 79.53 & 82.18 \\
\hline \multirow{2}{*}{ Low Self-esteem (B2) } & & & \\
\hline Total & & & \\
\hline
\end{tabular}

First, because $\mathrm{F}_{\mathrm{o}}$ between columns (4.05) is higher than $\mathrm{Ft}{ }_{(0.05)}(4.00)$, the difference between columns is significant. Therefore, Ho is rejected. It means that teaching speaking using Puppet media to the second grade of one of junior high schools in Semarang Regency in the academic year of 2014/2015 is significantly different from the one using Picture media. The mean score of the students taught by using Puppet media (81.60) is higher than the mean score of students taught by using Picture media is (79.12). Thus, it could be concluded that Puppet media is more effective than Picture media to teach speaking to the eighth grade of one of junior high schools in Semarang Regency in the academic year of $2014 / 2015$.

Second, because $F_{o}$ between rows (8.76) is higher than $F_{t(0.05)}(4.00)$, the difference between rows is significant. Therefore, Ho is rejected. It means that students having high self-esteem are significantly different from those having low self-esteem. The mean score of the students having high self-esteem (82.18) is higher than the mean score of the students having low self-esteem (78.53). It could be concluded that students having high self-esteem have better speaking skill than students having low self-esteem at the eighth grade of one of junior high schools in Semarang Regency in the academic year of 2014/2015.

Third, because $\mathrm{F}$ interaction between groups (5.22) is higher than $\mathrm{Ft}_{(0.05)}$ (4.00), Ho is rejected. Therefore, there is an interaction between the two variables, the teaching media and self-esteem in teaching speaking to the eighth grade of one of junior high schools in Semarang Regency in the academic year of 2014/2015. 
After knowing the effects and the interaction of independent variables toward the dependent variable, it is also necessary to compare the mean of every treatment with the other means using Tukey test. This test is used to identify which means are significantly different from the other. The details could be seen in the Table 5.

Table 5. Summary of Tukey Test

\begin{tabular}{llllll}
\hline No & Data & $\mathbf{q}_{\mathbf{o}}$ & $\mathbf{q}_{\mathbf{t}}$ & $\boldsymbol{\alpha}$ & Status \\
\hline 1 & $\mathrm{~A}_{1}-\mathrm{A}_{2}$ & 4.03 & 2.83 & 0.05 & Significant \\
\hline 2 & $\mathrm{~B}_{1}-\mathrm{B}_{2}$ & 5.92 & 2.83 & 0.05 & Significant \\
\hline 3 & $\mathrm{~A}_{1} \mathrm{~B}_{1^{-}}$ & 6.08 & 2.89 & 0.05 & Significant \\
& $\mathrm{A}_{2} \mathrm{~B}_{1}$ & & & & \\
\hline 4 & $\mathrm{~A}_{1} \mathrm{~B}_{2-}$ & 0.38 & 2.89 & 0.05 & Not Significan 1 \\
& $\mathrm{~A}_{2} \mathrm{~B}_{2}$ & & & & \\
\hline
\end{tabular}

First, because $\mathrm{q}_{\mathrm{o}}$ between columns (4.03) is higher than qt at the level of significance $\alpha$ $=0.05$ (2.83), it means that Puppet media is significantly different from Picture media in teaching speaking. The mean score of the students taught by using Puppet media (81.60) is higher than the mean score of students taught by using Puppet media is (79.12). Thus, it could be concluded that Puppet media is more effective than Picture media to teach speaking to the eighth grade students of one of junior high schools in Semarang Regency in the academic year of 2014/2015.

Second, because $\mathrm{q}_{\mathrm{o}}$ between rows (5.92) is higher than qt at the level of significance $\alpha$ $=0.05$ (2.83), it means that the students having high self-esteem are significantly different from those having low self-esteem. The mean score of the students having high self-esteem (82.18) is higher than the mean score of the students having low self-esteem (78.53). It could be concluded that students having high self-esteem have better speaking skill than students having low self-esteem to the eighth grade students of one of junior high schools in Semarang Regency in the academic year of 2014/2015.

Third, because $\mathrm{q}_{\mathrm{o}}$ between cells $\mathrm{A}_{1} \mathrm{~B}_{1}$ and $\mathrm{A}_{2} \mathrm{~B}_{1}$ (6.08) is higher than qt at the level of significance $\alpha=0.05$ (2.89), it means that Puppet media is significantly different from Picture media to teach speaking to the students having high self-esteem. The mean score of $\mathrm{A}_{1} \mathrm{~B}_{1}(84.83)$ is higher than $\mathrm{A}_{2} \mathrm{~B}_{1}(79.53)$, it could be concluded that Puppet media is more effective than Picture media to the students having high self-esteem. 
Forth, because $q_{o}$ between cells $A_{1} B_{2}$ and $A_{2} B_{2}(0.38)$ is lower than qt at the level of significance $\alpha=0.05$ (2.89), it means that Puppet media is not significantly different from Picture media to teach speaking to the students having low self-esteem. And the mean score of $A_{1} B_{2}$ is 78.37 and $A_{2} B_{2}$ is 78.70 .

The following section discusses findings of this research by considering the result of data analysis: (1) The Difference between Students Taught by Using Puppet Media and Picture Media. The finding of this research reveals that there is a significant difference between teaching speaking using Puppet media and teaching speaking using Picture media. By using puppet, students become less inhibited when they are hidden behind the puppet by only handling it to move. Puppet is an ideal springboard for developing speaking skill. As states by Greensmith (2012), Puppet as a media for learning speaking raises an activity of puppetry which provides an opportunity for students to become comfortable exploring language and becoming expressive verbally. They are free to try on new personalities and take them off again, with a puppet on their hand, broadening their own in the process. Naylor, Keogh, Downing, Maloney \& Simon (2007) state that using puppet appears to have a positive effect on lessons: enhancing children's engagement and motivation, providing a stimulus for focused talk and investigation in science, raising the confidence of shy children, getting children to share their ideas and reveal their misconceptions, challenging children's ideas and misconceptions in a creative way, providing opportunities for the teacher to take on a different role, supporting effective classroom management, creating a context for the use of vocabulary.

Belfiore (2013) explaines that puppetry in the classroom aids students to speak aloud in a group setting. Not only that, puppet is also a wonderful visual aid for students, retaining their attention and encouraging them to participate in class. Students are more willing to learn when they are having fun. According to Jean Piaget theory, puppet play helps students develop creative skills and cognitive skills by forcing them to use their imaginations. They make up the roles, the rules, the situations and the solutions. They have to listen and understand the information before they have to transcode and use it to deliver in puppet play. Any puppet can encourage the quietest of students to start talking. They can help to 
develop their social and motor skills, and can meet the visual, tactile and emotional needs of the individual (Narayanan, 2012).

Teaching speaking by using picture as media is also interesting, but it can not depict motion as puppet does. If it is not unique, picture can seem uninteresting to pupils while it takes time and costs much to provide attractive pictures. The other reason is if the picture is small and unclear, it arouses problems in the teaching learning process since the students misunderstand about the pictures. In addition, according to Baranowska (2002) about the use of picture, students will understand what they see quickly and there is a danger that they attain the general meaning of pictures in an easy and rapid way without coding them into their minds. Because of that, they soon forget what they have learnt or do not care for exercises that give them the necessary practice.

In accordance with the explanation of the differences between both media above, it could be summed up that Puppet media has more complex and challenging activities which involves all the students being creative and having high self confidence and motivation in learning than Picture media does. It could be estimated that Puppet media is more effective than the Picture media to teach speaking. It could be proved that the significant difference between Puppet media and Picture media could be seen from the learning activities and the process of the students to be active learners. Thus, it could be concluded that Puppet media is more effective than Picture media in teaching speaking skill; (2) The Difference between Students Having High Self-Esteem and Students Having Low Self-Esteem. The finding of this research reveals that students having high self-esteem have better speaking skill than those having low self-esteem. The mean score of students having high self-esteem is higher than those having low self-esteem. Students who have high self-esteem generally feel good about their ability to participate, confident in social situations and happy with the way. Those who have high self-esteem do well the challenging speaking activity given by the teacher in their accomplishments and try hard to be successful. As a result, students with high self-esteem generally have a realistic assessment of their strengths and weaknesses. They have a better self-confidence, independent and cooperative attitude, optimistic, feeling comfortable with a wide range of emotions, and ability to solve problems. Page \& Page 
(1992) in Ariyani (2013) state that the behavior commonly seen in students with high selfesteem is active, curious about surroundings, makes wide variety of contact, happy, confident; does not whine for what cannot be had.

On the other hand, students with low self-esteem tend to feel unworthy, incapable, and incompetent. They think that they have a negative view of life that turns into low risk taking ability. They tend to expect the worst, exert less effort on their tasks especially challenging demanding ones, achieve less success and, is afraid and pesimistic to do something. As stated by Jena (2002), low self esteem is a hopeless condition that keeps individuals from realizing their full potential. A person, who has low self esteem, feels incompetent, unworthy, and incapable. In fact, persons with low self esteem feel so poorly about themselves.

By virtue of the above explanation, it could be stated that the students whose selfesteem is high will be much easier to follow any speaking activity given because they are more motivated, creative, and having self-confidence to find the solution out when they find some difficulties in teaching and learning process. On the contrary, the students whose selfesteem is low will find it easy to get stuck in involving in the activity given by the teacher. Thus, it is obvious that the students, whose self-esteem is high, have better speaking skill than those whose self-esteem is low; (3) Interaction between Teaching Media and Students' Self-Esteem in Teaching Speaking.

The choice of media will influence student's achievement, especially in teaching speaking. In speaking class the teacher must use suitable media in order to get the students more active and get involved. Puppet media raises positive activities to enhance the students' speaking skill. The use of puppets provides an opportunity for students' expression through social aspects of communication. Through puppet plays, students can improve their proficiencies in oral language, involvement, and motivation. By the nature of this media, the activities created are really demanded for students who are active, creative, having high confidence, having high capability, having high self-worthy, and having belief of success to do challenging activities. Naylor et al. (2007) say that puppets can provide a useful 
mechanism to enhance children's engagement and to promote talk involving reasoning in primary lessons.

The students having high self-esteem usually have high motivation and belief to learn something. They will face their fear and anxiety as a challenge. They also have positive attitude towards the lesson by encouraging and supporting themselves to learn. They are energetic and capable to develop and enhance something. The activities are intended to encourage the students to develop conversation skills as risk taking, challenging and apropriate responses in a conversation and also develop sense of a story by exploring their capability in delivering it by involving themselves in a plot of story as one of the characters. They are expected to have high confidence and believe to be able to do the activities. As Lawrence (2006: 8) says, the child with high self-esteem is likely to be confident in social situations and in tackling school work. He/she will have retained a natural curiosity for learning and will be eager and enthusiastic when presents with a new challenge. They are also more active and creative in class and do not affraid in making mistakes. By considering the explanation, the puppet is suitable media to teach speaking to the students whose selfesteem is high.

On the contrary, the students with low self-esteem likely to give up or go through the motions of trying without really giving their best. They are afraid and pessimistic to do something challenging. The students with level of low self-esteem faced to be worst, less effort on their tasks, demanding the unchallenging activity, and achieving less success. They are afraid to speak and to take a risk in making mistake. They tend to choose an easy activity to do that will not demand them to do something different that they have to be brave, creative, and active. The students with low self-esteem find difficulties in the class, because they are mildly passive, tend to avoid new experiences, have limited contacts, shy and avoid getting problems (Page \& Page, 1992 in Ariyani, 2013). The activities created by using picture as media to teach speaking are also accordance with the characteristics of students having low self-esteem. At the beginning stages, the teacher facilitates the students by giving model to the activity by introducing the outline of a story by using picture as a media supported and then they work in group activity. By using picture, the students tends to do 
easier activity that they only tell what is drawn. The students having low self-esteem need guidance and support in learning and the use of picture serves students guidance through its activity created. It is suitable with the characteristics of the students having low self-esteem. The students are less creative in the class and they just become the followers. Although picture is interesting and easy to prepare, it possesses the characteristic which make the students tend to be passive, avoid new experience and do easy activity. Therefore, the use of picture media is more effective for students having low self-esteem. Based on the explanation, it could be concluded that there is an interaction between teaching media and students' self-esteem for teaching speaking.

There are some related previous studies in accordance with the variable of the reasearch conducted by the writer. First, research by Naylor, Keogh, Downing, Maloney, and Simon (2007) entitled The Puppets Project: Puppets and Change in Teacher Practice set out to investigate whether the use of puppets can provide a stimulus that will generate the kind of talk that helps thinking and reasoning in science. A major aim of the project was to provide a resource for teachers that would help them to enhance their practice by increasing the opportunities for children's talk that promotes thinking and reasoning and to become more dialogic in their teaching. The data show a decrease in the number of non-reasoning questions and an increase in the use of reasoning questions when puppets were used. This is consistent with the way that puppets present a problem to the class. When teachers used puppets they were more likely to ask open, thought-provoking questions which created opportunities for children's talk. This contrasts with their typical science lessons, which were more dominated by recall questions. There was a decrease in the amount of information provided by the teachers and an increase in the use of argumentation in science lessons when puppets were used. This created more opportunities for children's thinking and reasoning talk in the puppets lessons compared to the typical lessons without puppets. Again this indicates a shift in teaching style towards more thought-provoking lessons. It appears that the use of puppets has enabled the teachers to become more dialogic in their science teaching, and that introducing puppets into the classroom has influenced some 
fundamental aspects of their pedagogy. Chi-squared tests show that each of the changes indicated above is significant.

On the contrary with the previous study, the research conducted by the writer placed the students as the subject using the puppet as their media of learning speaking. The process of teaching and learning was focussed on the students' activity in telling story by using media to help them provoking speaking skill. The teacher placed herself only as the facilitator. It emphasized the active participation of the students in using puppetry in telling story as vehicles for the creation of opportunities to increase their English skill. Through the use of puppetry, it can gain the students' attention, and provide an interactive experience stimulating their creativity and the desire to share thoughts and ideas in doing fun puppetry story telling experience. The writer also compared puppet with picture to find out which media is more interesting and effective to enhance the students' speaking skill.

The other related previous study is by Nasution (2009) entitled Story-telling Technique Using Puppets to Improve the Speaking Ability of the Students of MTsN Tangerang II Pamulang. The purpose of this study is to improve students' skills in speaking through storytelling techniques using puppets in terms of the content of the story and storytelling. Based on the findings it can be concluded that the technique of storytelling using puppets is very effective to improve students' engagement in the learning process and to increase the value of speaking student achievement. Associated with stories and puppets as media and teaching materials, teachers are advised to provide media and material which were interesting according to the needs of the students. On the contrary, this writer's research was not only focused on the media used but also the psychological aspect which influenced the students in learning speaking such as self esteem and the previous researchers do not investigate it. It provided the best way to teach which apropriate with the students' condition. The main concern of this reserach was to see if such an interaction could be detected among students' skill in oral production, covering the five components of vocabulary, grammar, pronunciation, fluency, and content and media of learning and students' self esteem. As it was shown, the level of learners' self-esteem has a significant effect on students' speaking skill. So it might be helpful if teachers or other researchers pay more attention to their students' level of self-esteem and try to enhance it. Also considering the media used was important for decision making purposes since it affects teaching learning process. The findings may be interpreted to mean that those who have higher levels of selfesteem are more creative, more risk taking and more prepared to share their views with others regardless of whether, lexically or grammatically, they produce what can be regarded as accurate or standard or even correct English both accuracy and fluency, something which can perhaps take care of itself in the process of communication. Those caracters building are not investigated by the previous study. 


\section{CONCLUSION}

In accordance with the hypothesis testing, research findings are: (1) Puppet media is more effective than Picture media in teaching speaking. Considering with the first conclusion of this research, there are some suggestions addressed to English teachers, students, school, and other researchers. (a) English teachers, this study can offer an effective and efficient media to apply in teaching speaking. In implementing this media, they should have a preparation to implement this media effectively. They should understand the concept as well as strength and weakness of this media in order to avoid obstacles which may appear in the teaching and learning process. (b) Students, since puppet media is a new media for the students, the unique interesting and joyful learning experience of puppet media make them more enthusiastic in the classroom activities than monotonous learning media they used to be using. Puppet media also enables the students to be optimist, creative and active in exploring ideas when they are retelling a story. So, the students should be more active in teaching learning process in order to improve their speaking skill. (c) School, by knowing that Puppet is an effective media to teach speaking, the school should facilitate and support the implementation of this media by providing many resources deal with the procedure of using this media effectively and efficiently and requirements to make this media attracting for the students. Furthemore, after the process of the implementation, the school should give more concern on the effects of this media to teach speaking in order to observe whether it is done properly or not. The school also should do some evaluation if there were problems in implementing this media. And (d) Other researchers, they should be able to investigate something new and beneficial for teaching and learning development. They should be able to learn and understand the core of teaching media by reading some scientific sources such as journal or related research and following seminar or workshop, etc. Then, they can implement a new teaching media and the findings should inspire the other researcher and English teacher to do further study or find another new media dealing with teaching English especially speaking skill. (2) The students having high level of self-esteem have better speaking skill than those having low self-esteem. There are some suggestions addressed to English teachers and students related to the second conclusion of this research. (a) English 
teachers, the result of the media applied is also affected by the students' characteristics. Not all of the students feel comfortable with a particular media during the teaching and learning process. As proved in this research, puppet media is more suitable for the students with high level of self-esteem. Meanwhile, picture media is more suitable for the students with low level of self-esteem.

Therefore, it is really important for the teacher to know the students' characteristics in order to create a good and appropriate situation in a class before implementing this media in order to make the class interesting and not monotonous. And (b) Students, by knowing their level of self-esteem, students need to adjust themselves to the media used by the teacher in order to gain a higher achievement of speaking skill. They also must manage their self-esteem well because it can influence their speaking skill. (3) There is an interaction between teaching media and self-esteem to teach speaking. Based on the last conclusion, the writer constructed suggestions for English teacher and other researcher. (a) English teachers, they should be able to select the most appropriate teaching media based on the students' condition. Self-esteem becomes one of the important considerations in teaching speaking. Thus, they should understand whether the media used can facilitate the students having high and low self-esteem to practice speaking. (b) Other researchers, since self-esteem is regarded as one of the psychological aspects which influence speaking skill. This research can be used as a consideration to enrich their references in improving speaking skill viewed from a psychological point of view, self-esteem.

\section{REFERENCES}

Agil, Kho. 2012. Teaching Speaking through Visual Media. Retrieved from http://artcorners.blogspot.com, accessed at June 12

Ariyani, Y. N. 2013. The Effectiveness of Reap in Teaching Reading Viewed from Students' Self-Esteem. Thesis. English Department of Graduate Program. Surakarta: Sebelas Maret University.

Baranowska, M. 2002. Valuation of Visual Aids. Retrieved from http://www. edukacja.edux.pl/p-15478-valuation-of-visual-aids.php.

Belfiore, C. 2013. Puppets Talk, Children Listen. TEACH Magazine. Retrieved from http://www.teachmag.com, accessed at April 1 
Bell, J. (Eds). 2001. Puppet, Masks, and Performing Objects. New York University and Massachusetts Institute of Technology.Previously published as a special issue of The Drama Review (Vol. 43, no.3, Fall 1999)

Charles, J. 2007. What Is Self Esteem and How Do I get It?. Retrieved from http://www. counseling directory.org.uk/ counselloradvicel4.html

Florez, M. A. 1999. "Improving Adult English Language Learners' Speaking Skills". ERIC Digest. (ERIC Document Reproduction Service No. ED: 435204)

Fulcher, G. 2003. Testing Second Language Speaking. Harlow, England: Longman.

Gerlach, V. S. and D.P, Elly. 1980. Teaching and Media, a systematic Approach. New Jersey: Prentice Hall.

Greensmith, A. 2012. Puppets in Education. Retrieved from http://www.creativityinstitute.com/puppetsineducation.aspx

Hornby, A.S. 1995. Oxford Advanced Learner's Dictionary (Fifth Edition). New York: Oxford University Press.

Hymes, D. 1972. On Communicative Competence. Middlesex: Penguin Education.

Jena, A. 2011. Different Types of Self Esteem. Retrieved from http://www.projectguru.in/ publications/types-of-self-esteem

Kalanzadeh, G. H., Mahnegar, F, Hassannejad, E., \& Bakhtiarvand, M. 2013. The Influence of EFL Students' Self-Esteem on Their Speaking Skills. IJLLALW. Volume 2 (2), February 2013; 76-83.

Lawrence, D. 2006. Enhancing Self-Esteem in the Classroom. $3^{\text {rd }}$ edition. London: Paul Chapman Publishing.

Mackenkchnie Jean L. 1980. Webster New Twentieth Century Dictionary Unabridge: William Collins Publisher.

Narayanan, K. 2012. The Importance of Puppet. Retrieved from http://www.slideshare.net/kokilavaaninarayanan/the-importance-of puppets.

Nasution, N. 2009. Story-telling Technique Using Puppets to Improve the Speaking Ability of the Students of MTSN Tangerang II Pamulang found that the speaking ability of the VIII grade students of MTsN Tangerang II Pamulang in the academic year of 2008/2009. Retrieved from library.um.ac.id

Naylor, S., Keogh, B., Downing, B., Maloney, J., and Simon, S. 2007. The Puppets Project. Paper presented at the European Science Education Research Association Conference, Malmo, Sweden. Accessed at August

Reidmiller, Sandra M. 2008. Benefits of Puppet Use. The Benefits of-Puppet Use as a Strategy for Teaching Vocabulary at the Secondary School Level with Students Who Have Mixed Learning Disabilities.Accessed at December

Rubio, Fernando. 2007. (Eds). Self-Esteem and Foreign Language Learning. Newcastle: Cambridge Scholars Publishing.

Thornbury, Scott. 2005. How to teach speaking. Harlow, England: Longman. 